\title{
RIGHT OF PARTICIPATION IN BUSINESS AS MATRIMONIAL PROPERTY: THE MALAYSIAN EXPERIENCE
}

\author{
Zuhairah Ariff Abd Ghadas* and \\ Norliah Ibrahim**
}

\begin{abstract}
It is a deep wish of 'most' married couples that the marriage will last until 'death do as part.' Nonetheless, despite this wish, it is often found that a crisis occurs between married couples when it comes to money matters, more so if the concern is about a business which both parties foresee as a source of wealth.The right of participation in business is more than the right to share profits of the business. It also involves the management right and decision making power. Upon a divorce, it is common for the lucky ex-spouse to get certain percentage of shares in the business and therefore entitled to certain amount of dividend annually but rarely does one find the right to participation in the business is retained or given to the ex-couples. Whilst in practice the right to participate in the business is more significant and
\end{abstract}

Assistant Professor, Private Law Department, Ahmad Ibrahim Kulliyyah of Laws, International Islamic University Malaysia.

Assistant Professor, Islamic Law Department, Ahmad Ibrahim Kulliyyah of Laws, International Islamic University Malaysia. 
worth more than the shares! This article looks into participation rights in business as part of the matrimonial property in the due course of a divorce.

\section{INTRODUCTION}

Matrimonial property disputes is one area of law, which is daily litigated before the registrars and judges and is invoked after a divorce. Some divorces conclud smoothly but in some cases the parties will fight over practically everything of what has been accumulated throughout their marriage.

The normal disputes of matrimonial property is about tangible assets which were acquired during the marriage but many divorced couples, do not realize the bigger potential of intangible assets such as right to participate in the business which was set up during the marriage. The common pattern of distribution of business as matrimonial property is entitlement to shares or shareholding and/or business assets. There is no doubt as to the money worth of these two but in the actual fact, the right to participate in the business or the right to ownership, worth more than the quantum of the shares or the business assets.

\section{DEFINITION OF MATRIMONIAL PROPERTY (HARTA SEPENCARIAN)}

The statutes in Malaysia are silent with regard to the definition of the matrimonial property. Even though the Married Women Act (Revised 1990) is the main statute which deals with the married women's property, no reference is made to the term matrimonial property. The Law Reform (marriage and Divorce) Act 1976 (hereinafter referred to as the LRA) also leaves the term undefined and this failure has led to uncertainty in deciding what should and should not be included in the division. However, generally matrimonial property refers to any property, which is acquired during the marriage either by the joint effort or the sole effort of the party. It also includes property, which is owned before the marriage provided that it has been substantially improved by the other 
parties or by both parties during the marriage. ${ }^{1}$ In the case of Ching Seng Woah v Lim Shook Lin, ${ }^{2}$ Shankar J said that:

“...the expressions refer to the matrimonial home and everything which is put into it by either spouse with the intention that their home and chattels should be a continuing resource for the spouses and their children to be used jointly and severally for the benefit of the family as a whole. It matters not in this context whether the asset is acquired solely by the one party or the other or by their joint efforts. Whilst the marriage subsists, these assets are matrimonial assets. Such assets could be capital assets. The earning power of each spouse is also an asset." 3

The above definition clearly indicates that matrimonial property should cover anything that is acquired during the marriage. The definition is wide enough so as to cover the earning power of the spouse even though the quantification of the amount may lead to another dispute.

The above finding corresponds to the decision of Lord Denning in the case of Wachtel v Wachtel ${ }^{4}$ where matrimonial assets should refer to those things, which are acquired by one or the other or both of the parties. This must be coupled with the intention that it should be continuing provision for them and their children during their joint lives, and used for the benefit of the family as a whole. The judge divides the matrimonial assets into two parts; assets "of a capital nature" such as the matrimonial home and its furniture and "revenue producing nature" which include the earning power of husband and wife. The finding of Lord Denning conforms with the decision of Lord Diplock in the case of Pettit v Pettit ${ }^{5}$ where matrimonial property or family assets means "property whether real or personal, which has been acquired by either spouse in contemplation of their marriage or during its subsistence and was intended

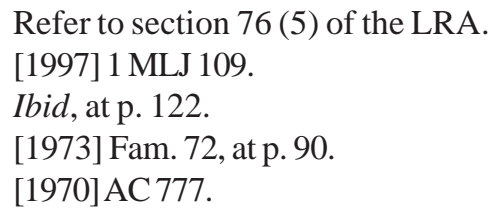


for the common use and enjoyment of both spouses or their children." 6 The above cases show that the English courts by using the word "family assets," describe matrimonial property as property in which both spouses should have some interest either because of the way in which it was acquired or because of the manner in which it was used. ${ }^{7}$

While for the Muslim, the definition section of the IFLA defines it as a "property jointly acquired by husband and wife during the subsistence of marriage in accordance with the conditions stipulated by Hukum Syara,." ${ }^{\circ}$ The judges in the decided cases also give a definition of harta sepencarian which basically refers to any property acquired during the marriage in which both parties contributed to its acquisition. In the old case of Hujah Lijah binti Jamal v Fatimah binti Mad Diah ${ }^{9}$ Briggs J. defined harta sepencarian as "property acquired during the subsistence of their marriage by a husband and wife out of their resources or by their joint efforts. The acquisition referred to may be extended to cover enhancement of value by reason of cultivation or development." 10 In pursuant to that, there was no reason for the wife, being a lawful widow, not to get one-half of the property bought originally from savings which accumulated from a piece of land inherited from her parents, even though it was registered in the name of the deceased husband.

In the case of Yang Chik v Abdul Jamal, ${ }^{11}$ the learned Kadhi said to the effect: "the concept of harta sepencarian is of the property that is acquired during the marriage with both the husband and wife contributing by the joint efforts or money to acquire the property."

Harta sepencarian in actual fact is not only confined to both their efforts in acquiring the property but extends further to cover their contribution whether formal or informal. This principle is best illustrated in the case Piah binti Said v Che Lah bin Awang ${ }^{12}$ where the Kadhi Besar of Penang defined the term as:

\footnotetext{
Ibid, at p. 819.

7 See the English Law Commission (Family Property Law), the Law Commission Published Working Paper, No. 42, para 0.24 at p. 15.

$8 \quad$ Refer to section 2 of the IFLA.

9 [1930] 16 MLJ 63.

$10 \quad$ Ibid, at p. 63.

11 [1985] 6 JH. 146.

12 (1983) 3 JH 220.
} 


\begin{abstract}
"Property acquired jointly during the subsistence of the marriage as result of joint efforts of the parties. This would arise in cases where the parties were either employed in similar occupations or otherwise and whether the contributions by the parties were formalized or not, and irrespective of whether there was a clear division of functions or otherwise.”13
\end{abstract}

From the above definition, it is clear that harta sepencarian is basically refers to any property which is acquired during the marriage, either by the joint effort or the sole effort of the parties as long as there is a contribution either directly or indirectly by the party who does not acquire the property. It is based upon "recognition of the part played by a divorced spouse in the acquisition of the relevant property and improvement done to it (in cases it where it was acquired by the sole effort of one spouse). It is due to this joint effort or joint labour that a divorced spouse is entitled to a share in the property acquired (during coverture). As long as the claimant has assisted in the working of it, the law presumes that the property was harta sepencarian and it therefore falls on the other spouse who denies the claim to rebut the presumption." ${ }^{14}$

Thus, if formerly the claim on harta sepencarian usually in the form of land, matrimonial houses and animals used to work the land, it has developed as to include moveable and immovable property like household goods and furnishing, inline with the life style and the purchasing power of society. ${ }^{15}$ It might also include joint bank accounts, compensation paid for land acquired by the government, ${ }^{16}$ shares registered in the name of either spouse, ${ }^{17}$ as well as business assets which has been acquired during the marriage. ${ }^{18}$

\footnotetext{
$13 \quad$ Ibid, at p. 223.

14 Ibid.

15 Mimi Kamariah, Family Law in Malaysia, Malayan Law Journal, Kuala Lumpur, 1999, p. 366.

$16 \quad$ Rokiah bte Haji Abdul Jalil v Mohammad Idris bin Shamsuddin (1410) JH 111; [1989] 3 MLJ ix, Kamariah v Mansjur (1986) 6 JH 301.

$17 \quad$ Noor Jahan bt. Abdul Wahab v Md Yusuff bin Amanshah [1994] 1 MLJ 156.

18 Tengku Anun Zaharah v Dato’ Dr. Hussein [1980] 3 JH 12.
} 


\section{THE LAW ON MATRIMONIAL PROPERTY IN MALAYSIA}

In Malaysia, the law that governs the division of matrimonial property is the Law Reform (marriage and Divorce) Act 1976 (hereinafter referred to as the LRA). As its long title provides that it is an Act to provide for monogamous marriages and the solemnization and registration of such marriages and to amend and consolidate the law relating to divorce and to provide for matters incidental thereto, the division of matrimonial property is specifically dealt with in section 76 of the Act. The Act which generally applies not only to all persons in Malaysia but also to those residents outside Malaysia whose domicile is in Malaysia ${ }^{19}$ was enforced throughout Malaysia since the date of the enforcement of the LRA i.e. first March 1982. ${ }^{20}$

While for the Muslims, they are governed by the Islamic Family Law Act and Enactments. However for the purpose of this article, reference is made only to the Malaysian law as codified in the Islamic Family Law (Federal Territories) Act 1984, which is also the model followed by many other states in Malaysia.

\section{(i) Law Reform (Marriage and Divorce) Act 1976}

Section 76 reads:

“(1) The court shall have power, when granting a decree of divorce or judicial separation to order the division between the parties of any assets acquired by them during the marriage by their joint efforts or the sale of any such assets and the division between the parties any proceeds of sale.

(2) In exercising the power conferred by sub-section (1) the court shall have regard to-

\footnotetext{
$19 \quad$ See section 3 of the LRA.

20 See PU (B) 73/1982.
} 
(a) the extent of contributions made by each party in money, property or work towards the acquiring the assets;

(b) any debts owing by either party which were contracted for their joint benefit; and

(c) the needs of the minor children (if any) of the marriage,

and subject to those considerations, the court shall incline towards equality of division.

(3) The court shall have power, when granting a decree of divorce or judicial separation to order the division between the parties of any assets acquired by them during the marriage by the sole efforts of one part to the marriage or the sale of any such assets and the division between the parties any proceeds of sale.

(4) In exercising the power conferred by sub-section

(1) the court shall have regard to-

(a) the extent of the contributions made by the other party who did not acquire the assets to the welfare of the family by looking after the home or caring the family;

(b) the needs of the minor children, if any, of the marriage;

and subject to those considerations, the court may divide the assets or the proceeds of sale in such proportions as the courts think reasonable; but in any case the party by whose effort the assets were acquired will get a greater proportion.

(5) For the purposes of this section, references to assets acquired during marriage include assets 
owned before the marriage by one party, which have been substantially improved during the marriage by the other party or by their joint efforts."

Referring to the above provision, it is clear that section 76 of the LRA is dealing with the power of the court to order the division of matrimonial assets acquired during the marriage upon granting a decree of divorce or judicial separation. The section is divided into two parts, one is where the assets were acquired by joint effort which is provided for in sub section (1) and the other where they were acquired by the sole effort of one party to the marriage which is dealt with in sub section (3). For the first category, the court shall lean towards equality of division, subject however, to certain factors for consideration such as the extent of the contribution made by each party in money, property or work towards the acquiring of the assets. ${ }^{21}$ Besides, any debts owing by either party which were contracted for their joint benefit will also be considered without undermining the needs of the minor children, if any, of the marriage. $^{22}$

Similarly, for assets acquired by the sole effort of one party to the marriage, the court may divide the assets in such proportions as it thinks reasonable. ${ }^{23}$ However this is also subject to certain factors namely the extent of the contribution made by the other party who did not acquire the assets to the welfare of the family by looking after the home or caring for the family. ${ }^{24}$ Similarly, if there are minor children from the marriage, their needs shall be taken into account as provided for in section 76(4) (b) of the LRA. Provided, however, that in any case the party by whose efforts were acquired shall receive a greater proportion..$^{25}$

Hence, section 76(5) of the LRA further elaborates that for the purpose of this section, assets acquired during a marriage includes assets owned before the marriage by one party as well. Nevertheless, it is subject to the condition that the claimed property must be substantially improved during the marriage by the other party or by their joint effort.

\begin{tabular}{ll}
\hline 21 & Section 76(2) (a) of the LRA. \\
22 & Section 76(2) (b) and (c) of the LRA. \\
23 & Section 76(4) of the LRA. \\
24 & Section 76(4) (a) of the LRA. \\
25 & Section 76(4) of the LRA.
\end{tabular}


While for the Muslims parties, The IFLA actually provides an identical provision except for the words "matrimonial property" being substituted by "harta sepencarian" while divorce and judicial separation" are replaced with the words "talaq and when making the order of divorce." ${ }^{26}$

\section{RIGHT OF PARTICIPATION IN BUSINESS}

\section{(i) Scope}

In a business, right of participation in business generally refers to management rights or the right to make decision in the business. These rights actually go beyond right to profit sharing or shareholding. In a business structure, ownership and control are two distinct rights. The fact that a person holds shares or interest in the company does not necessary means that he/she has management right or control in the business. To determine the composition and distinction of ownership, the business structure/form is vital.

In any business form, whether it is an enterprise, a firm or a company, the real measurement of ownership lies in who has the power to decide for or control of the business. The management right or the decision making power is normally vested in the owner and few other persons. It actually depends on the business entities. For example, in a sole proprietorship, it is a one man business which means one owner and as such no other person is entitled to participate in the business except than the owner. There is no issue of sharing management or decision making rights in sole proprietorships.

On the other hand, in a partnership structure or a firm, the partnership law is clear that all partners may participate in the firm. ${ }^{27}$ This provision impliedly gives all partners the decision making right and it is up to the partners either to be an active partner by exercising the management right or to become passive partner by not taking active role in the management of the business. In both circumstances, partners will

$26 \quad$ Please refer to section 58 of the IFLA.

$27 \quad$ Partnerships Act 1961; s. 26. 
jointly liable for the business debts. ${ }^{28}$ No partners can be exempted form liability of the firm. This principle is known of unlimited liability. The unlimited liability regime which is imposed in partnerships structure is in fact the legal justification which underlined the law that all partners have management rights. As such, in a partnership structure the right of participation in business is/must be shared between all partners.

In a company structure, the ownership structure is a bit more complex than sole proprietorships and partnerships structure. In a company, there are two main decision making organs, namely the members and directors. Directors decide through the board of directors (BOD) meeting whilst the members decide through the company's meetings (AGM or EGM). Despite the ideal perspective of giving members the right to decide in the business, the real fact is that it is the BOD that has the management right, particularly in the running of the business. ${ }^{29}$ The members' rights are only exercisable in the company's meetings and it is only if and when the company calls for a meeting, that members may exercise their decision making right. If the company did not call for any meeting (which is upon the BOD to decide), members will not be able to exercise their voting rights. This highlights the fact that shareholding does not necessarily connote control. Shareholding indicates ownership but not necessarily control.

According to Dr Saleem Sheikh and Professor SK Chatterjee: ${ }^{30}$

'The divergence of interest between ownership and control had created a division of functions. Within the corporation, shareholders had only interests in the enterprise while the directors had power over it. The position of the shareholders had been reduced to that of having a set of legal and factual interests in the enterprise.'

$28 \quad$ Partnerships Act 1961; s.7 and s.11.

$29 \quad$ Article 73; Table A, Fourth Schedule of Companies Act 1965.

$30 \quad$ Dr Saleem Sheikh and Prof SK Chatterjee, "Perspectives on Corporate Governance,” in Dr Saleem Sheikh and Prof William Rees (eds), Corporate Governance \& Corporate Control, Cavendish Publishing Limited, London, (1995) at 40. 
As such, in a company structure, the fact that a person has bulk of shares does not automatically means that he/she has management or right to participate in the business. Another important principle to highlight is that in a company structure, the management right generally vested in the BOD which means that it must be shared between more than one person.

(ii)

\section{Position as matrimonial property}

The above discussion is important to highlight a guideline to determine whether right of participation is business is viable to treated as a matrimonial property. One important observation which can be highlighted is that it can only be treated as matrimonial property if the business form allows the rights to be shared. As discussed above, not all business forms allow sharing of participation rights. A divorced couple may claim certain proportion/value of a sole proprietorships business as matrimonial property but not in right of participation as the control it vested upon one person only.

On the other hand, in a partnership and a company structure, the divorced parties may claim right of participation in the business as matrimonial property because it can be shared.

In the English case of Wachtel vs Wachtel, Lord Denning M.R held that "the phrase 'family assets' is a convenient short way of expressing an important concept of matrimonial property. It refers to those things which are acquired by one or other or both of the parties, with the intention that they should be continuing provision for them and their children during their joint lives, and used for the benefit of the family as a whole. The judge divides the matrimonial assets into two parts; assets "of a capital nature" such as the matrimonial home and its furniture and "revenue producing nature" which include the earning power of husband and wife.

If the definition in Wachtel case is used as the judicial guideline of what is matrimonial property, then, there is no reason to exempt divorced couple to claim the right of participation in business as part of matrimonial property. As long as it can be proved that the business was established/acquired before or during marriage with the intention that it is for continuing provision for them and their children during their joint 
lives, and used for the benefit of the family as a whole, divorced parties should be entitled to claim some proportion in the business.

Despite this observation, the case law showed otherwise. In Koay Cheng Eng v Linda Herawati Santoso, ${ }^{31}$ the petitioner contended that the respondent was not entitled to any maintenance payments as she was a professionally qualified architect, licensed to practice in the UK and, hence, capable of earning a living in the UK, free from the responsibility of raising any children. The petitioner declared his monthly income at RM10,000. The respondent disputed this and submitted that the petitioner had failed to make a full and frank disclosure of his income. The petitioner also contended that the respondent is ineligible to a share of the matrimonial assets because she did not contribute towards the purchases of the properties. The respondent, on the other hand, submitted that she is entitled, under s.76(1) and (2) of LRA, to half of all the matrimonial assets, including the properties and motor vehicles owned by the petitioner, a share in the petitioner's ENT clinic, and an equal share in the petitioner's provident fund contributed during the subsistence of the marriage.

The court held that the petitioner's contention that the respondent should not be paid any maintenance was unsustainable. The parties had been married for 17 years and the respondent had hoped for the marriage to survive. The respondent had sacrificed a career as an architect to follow the petitioner in his various postings before they moved to Malaysia 11 years ago. It would be a grave injustice to not order maintenance in favour of the respondent.

The court also held that properties acquired by the parties in Malaysia were paid for mostly with the moneys repatriated from the UK. Some of such properties were subsequently disposed of and the proceeds were used to purchase other properties. The respondent was able to show a direct contribution in relation to the purchase of the properties in the UK and consequently, she would be entitled to an equal share in the properties purchased in Malaysia. However, from the evidence, it is found that the respondent was never involved in the setting up or management of the petitioner's clinic and as such, she was unable to prove her claim of having contributed to the clinic. 
In deciding the above judgment, the judge made sole reference to Sivanes a/l Rajaratnam v Usha Rani a/p Subramaniam ${ }^{32}$ whereby the Court of Appeal upheld the decision of the High Court that upon the divorce, the wife was entitled to a share of the clinic as matrimonial property because the wife had contributed to the setting up of the clinic by among others:

(i) standing as guarantor for banking facilities;

(ii) selling the family car to tide over the difficult period; and

(iii) Utilising joint savings in the opening of the clinic.

Another interesting case law to highlight the approach of court in deciding interest in business as part of matrimonial property (for Muslim) is Boto' binti Taha v Jaafar bin Muhamed. ${ }^{33}$ In this case the parties were married in 1966. At the time of the marriage the plaintiff-wife worked as a coffee-shop assistant and the defendant-husband carried on a fishmonger business in Dungun. The business of the defendant prospered and during the marriage he bought the matrimonial home, a piece of land, 4 fishing boats, fishing nets and a fish stall. The marriage ended in a divorce in 1974 and on the divorce the defendant only paid the plaintiff her maintenance for the period of eddah. The plaintiff applied to High Court for a declaration that she was entitled as harta sepencarian (matrimonial property) to one-half share in all the properties acquired during her marriage to the defendant and to one-half of all the income derived from the properties since their divorce.

The court held that harta sepencarian is based on customs practiced by the Malays and rests upon the legal recognition of the part played by a divorced spouse in the acquisition of the relevant property and in improvements done to it, in cases where it was acquired by the sole effort of one spouse only. It is due to this joint effort or joint labour that a divorced spouse is entitled to a share in the property. The fact that the plaintiff accompanied the defendant in his business trips and giving up employment because of the marriage must amount to her joint efforts in the acquisition of those properties. Interestingly, the court further held in this case that even though the plaintiff did not take direct part in the 
defendant's fish business, her constant companionship was responsible for the defendant's peace of mind which enabled him to function effectively as a businessman. The evidence shows that she was helping the plaintiff's business indirectly as a partner in his business trips. As such, the properties which are the subject of the present suit are harta sepencarian.

The above cases law highlighted the approach of the Malaysian court in determining right of divorced parties to claim shares in business as matrimonial property. It can be seen that it if parties did not contribute to the business, direct or indirect or was never involved in the management of the business, direct or indirect, he/she would not be entitled to the business as part of matrimonial property. Some degree of participation is required to indicate interest of the parties in the business.

Interest in business as part of matrimonial property, particularly value of shares is indeed common in Malaysia. This can be seen in many case law such as the above mentioned cases. Nonetheless, issue of right of participation in business as part of the matrimonial property is very rare except in some case relating to divorce settlement. For example, in the high profile divorce case of Datuk Seri Mohd Effendi Norwawi and Zariah Hashim @ Farida Effendi, the divorce settlements includes transfer of his shares in Encorp Utility Sdn Bhd to the ex-wife ${ }^{34}$ and even after the divorce, Madam Zariah hold a position as the non-independent Executive director in Encorp Utility Sdn Bhd. ${ }^{35}$ This means that Madam Zariah obtained both shareholding and participation rights in the business. From the evidences, there is no doubt on active participation of Madam Zariah in the company/business during the marriage and this is perceived as one of the reasons that she claimed for both shares and participation right in the company as part of the divorce settlement.

\section{CONCLUSION}

In deciding the divorce settlement and matrimonial property cases, the court normally refers to the statutory and judicial guideline. This is

\footnotetext{
$34 \quad$ M.Mageswari, “Effendi case settled.” The Star, Thursday October 19, 2006. Retrieved from http://www.thestar.com.my/news/story.asp?file=/ 2006/10/19/courts/15767577\&sec=courts on 5 Jan 2007.

35 Retrieved from http://www.igdexchange.com/bod.asp at 5 Jan 2007.
} 
indeed commendable as the main method to justify legal judgment. Nonetheless, it is perceived that there are other aspects which need to be highlighted in determining the composition of matrimonial property. For example, in the case of rights of participation in business, the court must firstly, take into consideration the business structure, whether it allows the parties to share or to be jointly involved as decision maker. It is only viable to grant right of participation as part of matrimonial property if the business structure allows the decision making power to be shared, for example in a company and/or a partnership but not in a sole proprietorship.

Secondly, the court may also take into consideration the nature of the business, whether it is a public related business or a family business, which was established and meant to continue for the children/family benefits despite the divorce. In the latter, the divorced parties should be allowed to have participation rights in the business, particularly if the parties represent continuous interest of the family and to avoid the family ownership structure falls into the hand of outsiders.

It is also interesting to see the approach of the Malaysian court in determining interest in business a part of matrimonial property. From the case law, it is clear that the court requires certain/some contribution/ participation of the parties in the business during the marriage as an element to determine rights in the business as part of matrimonial property. ${ }^{36}$ In such circumstances, the interpretation of participation seem to be vary, for example in Koay Cheng Eng v Linda Herawati Santoso in comparison to Boto'binti Taha v Jaafar bin Muhamed. In the latter case, the court held that companionship as a wife is sufficient to indicate contribution/participation in the business whilst in the former case, it is observed that the court required more than mere companionship.

It is proposed that in future, the Malaysian court could expand its approach in deciding matrimonial property by taking into consideration the right of participation/management rights and not merely confine the distribution by reference to the amount of shares or value of the parties' interest (money worth) in the business. 